\title{
Albanon
}

Revistë kulturore

\section{Normalja e Elbasanit dhe mjedisi universitar}

(Kumtesë për 110-vjetorin e shkollës Normale)

Peçi NAQELLARI

Hapja 110 vjet më parë e shkollës së parë të mësuesisë në Shqipëri, të cilën të gjithë edhe në histori, por edhe sot e njohim me emrin Normalja e Elbasanit, është një prej ngjarjeve çelës, etapë e pashmangshme në kalendarin e zhvillimit historik dhe kulturor të popullit shqiptar. Shkolla Normale për disa dekada u shndërrua në një institucion, ku mësuesit përgatiteshin si mësimdhënës të brumosur me idealet e atdhetarisë e shqiptarizmës, me dijet dhe frymën që vinte nga Rilindja Kombëtare, me njohjen dhe zbatimin e shumë prej teorive bashkëkohore evropiane në fushën e pedagogjisë, psikologjisë e shkencave të zbatuara.

Normalja si institucion vendosi themelet në disa drejtime të dijes e mendimit shkencor shqiptar. Si institucion u shndërrua në qendër të kultivimit e zhvillimit pedagogjik shqiptar. $U$ hartuan dhe u zbatuan plane, programe e tekste mësimore të përshtatura me kërkesat e kohës. Gjithashtu, ajo u shndërrua në një qendër të eksperimentimit e përvijimit të shkencave të zbatuara. Nëpërmjet botimeve të ndryshme u publikuan dijet, kërkimet dhe arritjet në fusha të ndryshme, të cilat u bënë një shtysë e parë për studiuesit e rinj në shumë fusha të shkencës shqiptare. Janë këto vlera që na bëjnë të pohojmë me krenari se Normalja me veprimtarinë e saj pedagogjike dhe shkencore për nivelet e arritura, fiton statusin e merituar të Universitetit të parë të përgatitjes së mësuesve në Shqipëri.

Këto vlera kanë ushqyer ndërgjegjen intelektuale të profesoratit të Institutit të Lartë Pedagogjik "Aleksandër Xhuvani”, themeluar më 1971 dhe Universitetit të Elbasanit "Aleksandër Xhuvani”, themeluar më 1991. Këto 
dy institucione lindën në të njëjtin truall, për më tepër si vijues të të njëjtit funksion dhe destinacion. Nga ana tjetër, ishte përgjegjësi intelektuale, shkencore e morale, të prireshin drejt atyre vlerave të përvijuara dhe të prodhuara në kushte dhe situata krejtësisht të tjera. Ai truall i begatë që ushqeu, rriti dhe zhvilloi Normalen, ruan forca ripërtëritjeje dhe zhvillimi, në evolucion e sipër.

Universiteti i Elbasanit, për disa dekada, ka një ecuri të vrullshme drejt përsosjes dhe zgjerimit të hapësirave në përgatitjen e mësuesve dhe specialistëve të fushave të ndryshme. Kapacitetet intelektuale dhe në vijim studiuesit e rinj, japin mundësi të reja zhvillimi.

Duke e parë Universitetin e Elbasanit "Aleksandër Xhuvani” si vazhdues i asaj tradite të shkëlqyer të përvijuar në Shkollën Normale, të atyre vlerave dhe kontributeve, duke patur njëkohësisht edhe përgjegjësinë që të imponon një traditë e kësaj natyre, duke e parë me një tjetër vizion, e vlerësojmë këtë përvjetor si 110 vjetori i Universitetit të Elbasanit "Aleksandër Xhuvani".

Duke kaluar natyrshëm në Universitet, Normalja Kombëtare ka marrë statusin e një shkolle të lartë dhe emri i saj bëhet i përjetshëm. Data e themelimit të shkollës së lartë në Elbasan dhe për rrjedhojë edhe në Shqipëri, rezulton 1 dhjetor 1909.

Kalimi i natyrshëm lidhet me:

- karakterin kombëtar të Normales,

- nivelin e lartë të profesoratit mbarëkombëtar,

- përvojën evropiane,

- dokumentacionin shkollor bashkëkohor,

- botimet e ndryshme,

- me praktikën e themelimit të universiteteve evropiane dhe amerikane.

Mësuesit sot përgatiten vetëm pranë shkollave të larta.

Universiteti i Elbasanit “Aleksandër Xhuvani” është një vijim i logjikshëm i destinacionit të Normales në përgatitjen e mësuesve dhe specialistëve të arsimit.

Kështu historikisht dhe shkencërisht, Universiteti i Elbasanit "Aleksandër Xhuvani” me të drejtë konsiderohet sot si Universiteti më i vjetër në Shqipëri, kjo falë panteonit të arsimit shqiptar, shkollës Normale.

Tradita e Normales, misioni dhe kontributi i saj përvijohen dhe janë të mishëruara në misionin dhe objektivat e Universitetit tëElbasanit "Aleksandër 


\section{Albanon}

\section{Revistë kulturore}

Xhuvani”, me pesë fakultetet e tij, Fakulteti i Shkencave Humane, Fakulteti i Shkencave të Natyrës, Fakulteti i Shkencave të Edukimit, Fakulteti Ekonomik dhe Fakulteti i Shkencave Mjekësore Teknike.

Në vijim të përpjekjeve, shembullit dhe figurës së mësuesve dhe normalistëve, personeli akademik i Universitetit, ka rritur dhe rrit në vijimësi pontecialet e veta intelektuale në veprimtarinë integruese mësimore dhe kërkimore shkencore. Kjo shprehet në treguesit për titujt dhe gradat shkencore, ku 72 veta nga personeli akademik i përkasin kategorisë profesor (profesor doktor dhe profesor i asociuar), rreth 90 veta i përkasin kategorisë lektor (doktor dhe docent) etj.

Në suksesin apo jo të një institucioni arsimor, të një shkolle që përgatit mësues dhe specialistë, janë të rëndësishëm disa tregues:

- Baza konceptuale dhe synimi në përgatitjen e kuadrit me kërkesat bashkëkohore.

- Ndërtimi i konceptit shkencor që pasqyrohet në lëndët dhe programet e studimit, duke u bazuar edhe në traditën e suksesshme.

- Kriteret pedagogjike apo akademike që do të udhëheqin mësimdhënien drejt përsosjes dhe integrimit evropian.

- Reputacioni dhe dinjiteti i personelit pedagogjik e akademik i bazuar në aftësitë profesionale dhe shkencore.

- Cilësia e disiplinave lëndore për formimin profesional duhet të jetë sa më shkencore dhe bashkëkohore.

Normalja, është Universiteti i parë pedagogjik shqiptar për përgatitjen e mësuesve, sepse janë plotësuar kushtet për një emërtim të tillë. Këtë e tregon raporti i drejtë në programet e Normales, midis veprimtarisë mësimore me veprimtarinë kërkimore shkencore. Përvoja tregon se me punë kërkimore merren mësuesit, por edhe nxënësi është një kërkues i vogël etj. Në arsimin e lartë veprimtaria kërkimore shkencore është kriteri bazë për statusin e tij.

Normalja e Elbasanit e plotësonte këtë kusht dhe ishte e orientuar drejt në veprimtarinë kërkimore shkencore dhe konkretisht kjo pasqyrohet si vijon:

- Në dokumentacionin shkollor si planet, programet lëndore etj.

- Në botimet e shtypit të kohës, të cilat ishin me karakter shkencor.

- Në shkrimet e botuara në organe të ndryshme për fushën e edukimit etj.

Në këto shkrime dhe botime pasqyrohet mendimi teorik i përpunuar, por edhe zbatimi i njohurive në praktikë (te revista "Normalisti" etj.). 
Pra, ashtu sikurse universiteti ka organet dhe botimet për veprimtarinë mësimorekërkimore, kështu vjen edhe tradita e Normales. Pra ne e shohim të aktualizuar traditën, duke u larguar nga miti i Normales vetëm me vlera arkivore. Kjo ka vlera jo vetëm profesionale, por edhe kombëtare për arsimin tonë.

Për këto vlera Shkolla Normale është nderuar me titullin "Nderi i Kombit" (në 105 vjetorin e saj).

Misioni i shenjtë i Normales, i kësaj vatre të dashur të arsimit shqiptar, shprehet te qytetaria, edukimi dhe ruajtja e vlerave më të mira, të cilat bashkojnë normalistët, qytetarët, studentët, pedagogët, autoritetet vendore dhe të zgjedhurit në 110 vjetorin e saj.

Historia e arsimit në Shqipëri ende nuk është shkruar plotësisht, sidomos roli i tij në jetën kombëtare dhe më gjerë. Ne jemi të bindur se nga Çdo rishikim dhe pasurim i historisë së arsimit, vendi dhe statusi i Normales vetëm do të lartësohet. Ajo i ka bërë vend vetes dhe ka krijuar mundësi evoluimi drejt progresit.

Normalja e Elbasanit mund të cilësohet pa mëdyshje si institucioni me rolin më të rëndësishëm iluminist gjatë gjysmës së parë të shekullit të 20-të. Ajo përgatiti rrethanat që më së fundi edhe Shqipëria të bëhej një vend me universitet dhe me shkolla të larta. Në këtë kontekst, Normales mund t’i njihet merita e padiskutueshme si shkolla e mësuesve, e cila lartësoi arsimin shqiptar në rrugën e rritjes, duke qenë edhe vetë një institucion që kreu për kohën funksionet e një universiteti.

Kalimi i natyrshëm i saj nëInstitut i LartëPedagogjik dhe më pas nëUniversitet, i përngjan dukurisë së rrathëve koncentrikë, ku tre rrathët simbolizojnë tre institucione, përkatësisht Normalen, Institutin dhe Universitetin, kurse qendra e tyre, truallin e begatë kulturëdashës dhe arsimdashës të Elbasanit.

Në këtë kontekst, historia e Normales dhe historia e Universitetit të Elbasanit "Aleksandër Xhuvani", nuk mund të ndahen midis tyre, janë në një simbiozë për historinë e arsimit shqiptar.

Universiteti i Elbasanit, duke e universitarizuar historinë e shkollës në këtë qytet dhe më gjerë, trashëgoi vlerat më të mira dhe vijon për dekada me radhë të jetë një prej kryeqendrave të mësuesisë. Universiteti i Elbasanit "Aleksandër Xhuvani" është zgjeruar dhe ka evoluar nga ana sasiore dhe cilësore; ka shtuar në vijimësi:

- numrin e programeve të studimit,

- titujt e diplomave, 


\section{Albanon}

Revistë kulturore

- departamentet dhe fakultetet,

- profesoratin,

- botimet,

- ciklet e studimeve,

- $\quad$ numrin e studentëve etj., duke u kthyer në një prej qendrave universitare më të rëndësishme në shkallë vendi.

Ai është shndërruar sot në mjedisin ku formohen edhe studiuesit e ekonomisë, të teknologjive të informacionit, të shëndetësisë dhe të disa fushave të tjera të jetës shoqërore. Kështu, nderimit të diplomës, misionit dhe kontributit të Normales, i shtohet edhe nderimi për diplomat, misionin dhe kontributin e Universitetit të Elbasanit "Aleksandër Xhuvani".

Pedagogët dhe studentët e këtij Universiteti gëzojnë një reputacion të veçantë, por edhe një privilegj se kanë krijuar breza që mburren se kanë qenë e ardhmja e vendit dhe në tërësi e kombit shqiptar. Kjo është arritje e rëndësishme për një institucion me një traditë të pasur që nga fillesat $\mathrm{e}$ Normales.

Prirur nga motive profesionale, ish nxënës e mësues të shkollës Normale kanë dhënë një kontribut të vlefshëm në lëvrimin dhe zbatimin praktik të mendimit didaktik e shkencor.

Mësues dhe ish nxënës të shkollës, me prirje të veçanta, e afirmuan vetveten si shkencëtarë të Shqipërisë. (Mahir Domi, Kolë Popa, Kolë Paparisto, Mustafa Demiri, Xhafer Qosja, Shaban Baxhaku, Uran Asllani, Mehmet Çeliku etj.)

Nuk është rastësi që trupi i parë mësimor që themeloi Institutin e Lartë Pedagogjik "Aleksandër Xhuvani” në vitin 1971 (sot Universiteti i Elbasanit "Aleksandër Xhuvani”), përbëhej nga ish nxënës e mësues të Normales (Vasil Kamami, Tomor Arianiti, Roland Popa, Agim Kurrizi, Mirjam Myftiu, Bardhyl Graceni, Xhemal Lufta, Hysen Shabanaj etj.)

Universiteti i Elbasanit "Aleksandër Xhuvani” ka dhënë një kontribut të çmuar për zhvillimin e arsimit kombëtar, në përgatitjen e mësuesve e specialistëve të fushave të ndryshme të shkencës, si dhe në përhapjen e dijes dhe kulturës, në vijimësi të traditave të shkollës Normale.

Nëpërmjet një game të gjerë programesh studimi, me 38 programe të ciklit të parë (bachelor), 48 programe të ciklit të dytë (master profesional dhe master i shkencave), 7 programe diploma profesionale dhe 2 programe të ciklit të tretë (doktoraturë), personeli akademik i Universitetit të Elbasanit "Aleksandër Xhuvani” është i angazhuar të përgatisë studentët të jenë reflektues nëpërmjet të mësuarit gjatë gjithë jetës, lider të ardhshëm të 
profesioneve, të bizneseve dhe të industrive, por njëkohësisht të jenë të përgjegjshëm dhe pjesëmarrës aktivë në jetën në komunitet.

Për misionin dhe kontributet, të dy institucionet, Normalja dhe Universiteti, parakuptojnë një bashkëmarrëdhënie të ngushtë dhe ndonëse këto dy institucione të rëndësishme, ndryshojnë nga njëri-tjetri në aspektin kohor, strukturor e statusor, kanë një lidhje të brendshme organike të dukshme ndërmjet tyre, pasi kanë ruajtur historikisht të njëjtat funksione e kanë zbatuar detyra të njëjta.

Normalja e Elbasanit ka synuar parametra të shkollave evropiane, duke patur një gamë shumë të gjerë funksionesh dhe synimesh. Këto funksione dhe synime janë aktuale edhe sot për arsimin në përgithësi dhe arsimin e lartë në veçanti.

Konkretisht në themel të platformës së arsimit të lartë dhe Universitetit të Elbasanit "Aleksandër Xhuvani", qëndron synimi kryesor ku Universiteti duhet të funksionojë si një qendër e rëndësishme e projektimit të zhvillimit rajonal dhe në këtë këndvështrim ky institucion duhet të vijojë punën e vet duke u thelluar jo vetëm në drejtim të përgatitjes dhe kualifikimit të specialistëve, por njëherësh të zhvillojë ato profile e programe studimi që janë më të kërkuara dhe në funksion të zhvillimit rajonal dhe integrimit.

\section{Bibliografi}

1. Materiale të Arkivit të Muzeut pranë Shkollës Normale të Elbasanit.

2. Materiale nga Historiku i Universitetit të Elbasanit "Aleksandër Xhuvani”.

3. Naqellari, P. (1999): Harmonizimi i dhënies së njohurive në shkencat e natyrës. Buletini shkencor UNIEL 199/2, numër special kushtuar 90 vjetorit të Normales.

4. Plangarica, T. (1999): "Normalja-Tradita, miti dhe e ardhmja" në "Normalja në fokus të bashkëkohësisë".

5. Programa e mësimeve të Shkollës Normale.

6. Revista "Normalisti” (1929, 1931, 1932, 1933, 1936, 1937).

7. Varoshi, L., Çeçi, N. (1999): Ndërprerja dhe tjetërsimi i traditës së Shkollës Normale. Buletini shkencor UNIEL 199/2.

8. Xhuvani, A. (1926): Didaktikë e edukatë. 